\title{
Tomasz Dębowski
}

Uniwersytet w Białymstoku, Wydział Ekonomiczno-Informatyczny w Wilnie e-mail: debal@poczta.onet.pl

\section{ZMIENNOŚĆ WIELOLETNIEGO BUDŻETU UNII EUROPEJSKIEJ - UJECIE RETRO- I PROSPEKTYWNE VOLATILITY OF MULTIANNUAL BUDGET OF THE EUROPEAN UNION - RETRO AND PROSPECTIVE APPROACH}

DOI: $10.15611 /$ pn.2018.509.05

JEL Classification: R5

Streszczenie: Podstawą do podjęcia tematu obejmującego problematykę zmienności wieloletniego budżetu unijnego jest zbliżająca się nowa perspektywa finansowa, w której spodziewać się należy istotnych przeobrażeń. Artykuł stanowi próbę porównania zmian zachodzących w kolejnych wieloletnich budżetach Unii Europejskiej po roku 2000. Celem artykułu jest ukazanie zmian budżetowych, jakie miały miejsce w trzech perspektywach finansowych (tj. w latach 2000-2006, 2007-2013 i 2014-2020), ich interpretacja i ocena oraz przyjrzenie się planowanym modyfikacjom konstrukcji budżetu przewidywanym w latach 2021-2027. Realizacja celu wymagała dokonania przeglądu i analizy poszczególnych działów w przekroju trzech ostatnich budżetów wieloletnich, ukazania i interpretacji wielkości wydatków oraz przybliżenia założeń, na których z dużą dozą prawdopodobieństwa oparte będą nowe Wieloletnie Ramy Finansowe.

Słowa kluczowe: budżet Unii Europejskiej, Wieloletnie Ramy Finansowe, wydatki budżetowe.

Summary: The upcoming new financial perspective, in which significant transformations are expected, is the basis for taking up the subject about volatility of the multiannual EU budget. This article is an attempt to compare the occurring changes in the next multiannual budget of the European Union after 2000. The presentation of budgetary changes, taking place in the three financial perspectives (i.e. in the years 2000-2006, 2007-2013 and 2014-2020) is the purpose of this article. There are also interpretation and evaluation of these changes and a look at the planned modifications of the budget structure expected in the years 2021-2027. Achieving the goal requires a review and an analysis of individual sections in the last three multiannual budget terms, presentation and interpretation of the amount of expenditures and approximation of assumptions, on which the new Multiannual Financial Framework will be based with a high degree of probability.

Keywords: European Union's budget, Multiannual Financial Framework, budgetary expenditure. 


\section{Wstęp}

Przyjmowanie wieloletniego budżetu Unii Europejskiej każdorazowo budzi emocje. Wobec zmian dokonujących się w strukturze terytorialnej Wspólnoty oraz w związku ze zmienną sytuacją gospodarczą w Europie, przeplataną lepszymi i gorszymi okresami, planowanie wieloletnich dochodów i wydatków budżetowych wymaga działań dostosowawczych. Stąd też każdy z dotychczasowych wieloletnich budżetów unijnych różnił się w stosunku do swoich odpowiedników z innych perspektyw finansowych. Wypracowano już wprawdzie stabilną formułę w zakresie przeprowadzania procedury budżetowej, uzgodniono też większość trwałych zasad, na których podstawie funkcjonuje budżet, jednak w samej konstrukcji budżetu i wielkości wydatków budżetowych zawsze uwidacznia się zmienność. Celem artykułu jest ukazanie zmian budżetowych, jakie miały miejsce w trzech perspektywach finansowych (tj. w latach 2000-2006, 2007- 2013 i 2014-2020), ich interpretacja i ocena oraz przyjrzenie się planowanym modyfikacjom konstrukcji budżetu przewidywanym w latach 2021-2027.

\section{Budżet Unii Europejskiej i Wieloletnie Ramy Finansowe - zagadnienia wprowadzające}

Budżet Unii Europejskiej (UE) jest zestawieniem dochodów i wydatków sporządzanym w walucie europejskiej (euro) na okres jednego roku (tożsamego z rokiem kalendarzowym). Począwszy od roku 1988, budżety roczne ustalane są z uwzględnieniem ram finansowych (aktualnie tzw. Wieloletnich Ram Finansowych), które określają roczne pułapy wydatków w ciągu kilku następnych lat. Budżet UE nie może przekroczyć poziomu $1,23 \%$ dochodu narodowego brutto (DNB) wszystkich państw członkowskich. W praktyce oscyluje ok. 1\% DNB. Z unijnego budżetu finansowane są wszelkie działania podejmowane przez Unię, polityki i programy pomocowe, a także jej administracja [Janiak 2015]. Budżet Unii Europejskiej może być rozpatrywany jako akt prawny, fundusz, plan finansowy [Cieślukowski 2006].

Rada Unii Europejskiej oraz Parlament Europejski uchwalają dochody i wydatki budżetowe $\mathrm{w}$ formie aktu prawnego. Istota budżetu w sensie prawnym przejawia się w nadaniu uprawnień Komisji Europejskiej w zakresie dokonywania wydatków oraz pozyskiwania dochodów, jednakże nie uprawnia jej do obciążania konkretnych podatników ciężarami podatkowymi, a także do wydawania środków budżetowych na konkretne cele. Wszystkie działania Komisji w tym obszarze oparte są na właściwych aktach wykonawczych do budżetu, m.in. regulacjach, dyrektywach czy decyzjach [Cieślukowski 2006].

Budżet unijny to także fundusz o charakterze ponadpaństwowym oraz redystrybucyjnym. Ponadpaństwowość przejawia się we własnych źródłach dochodów, będących uprzednio źródłami dochodów budżetów państw członkowskich. Wydatki 
dokonywane na terenie każdego z państw członkowskich również przesądzają, że budżet jest ponadpaństwowy. Ponadto to instytucje UE - posiadające autonomię finansową oraz organizacyjną - planują, uchwalają i wykonują budżet. Redystrybucyjny charakter budżetu przejawia się tym, że na początku jest on zasilany dochodami z własnych źródeł, a później środki te są wydawane zgodnie z określonymi zadaniami. Proces redystrybucji opiera się na takich cechach, jak: przymusowość, bezzwrotność i powszechność obciążeń na rzecz budżetu oraz brak ze strony Wspólnot wzajemnego bezpośredniego świadczenia [Cieślukowski 2006]. Budżet jest również planem finansowym działalności UE, który Komisja Europejska oraz podległe jej podmioty opracowuje i wykonuje. Zawiera dochody oraz wydatki spodziewane w okresie rocznym [Cieślukowski 2006].

Wieloletnie Ramy Finansowe (WRF) są dokumentem przekładającym priorytety polityczne UE na wielkości budżetowe. Są jednocześnie instrumentem dyscypliny i planowania budżetowego, ponieważ wielkość wydatków w budżetach rocznych musi uwzględniać pułapy określone w perspektywie finansowej. Tym samym dyscyplina wydatków budżetu UE jest najważniejszym celem WRF. Ponadto ustalanie wydatków w ujęciu wieloletnim zwiększa stabilność budżetu, ponieważ beneficjenci są w stanie przewidzieć poziom tych wydatków w kolejnych latach. Dzięki pułapom ustalonym w WRF współpraca między instytucjami zaangażowanymi co roku w przyjmowanie budżetu układa się lepiej niż w czasach, gdy perspektywa nie istniała. Rozporządzenie ws. Wieloletnich Ram Finansowych określa przede wszystkim maksymalne pułapy wydatków, jakie mogą przyjąć budżety roczne UE. W przypadku dwóch pozycji budżetowych, tj. polityki spójności i rozwoju obszarów wiejskich, określony zostaje wprost budżet wieloletni, czyli plan wydatków na dłuższy okres. Rozporządzeniu towarzyszy Porozumienie Międzyinstytucjonalne, zawierane przez Radę, Parlament Europejski i Komisję Europejską, określające zakres współpracy w sprawach budżetowych pomiędzy tymi instytucjami w celu sprawnego zarządzania finansowego. Ramy finansowe (określane też mianem budżetu wieloletniego) planowane są na kilka lat. Pierwsza perspektywa finansowa (tzw. pakiet Delorsa I) dotyczyła lat 1989-1993, druga (Delors II) lat 1994-1999, trzecia (Agenda 2000) lat 2000-2006, czwarta zaś (Nowa Perspektywa Finansowa) lat 2007-2013. Z początkiem 2014 r. rozpoczęła się piąta perspektywa finansowa obejmująca lata 2014-2020 [Janiak 2015]. Aktualnie toczą się rozważania na temat kształtu kolejnej perspektywy finansowej obejmującej lata 2020-2026.

Z uwagi na objętościową ograniczoność opracowania analiza retrospektywna wieloletniego budżetu Unii Europejskiej dotyczyć będzie wyłącznie strony wydatkowej rozpatrywanej w trzech okresach: 2000-2006, 2007-2013 i 2014-2020. Analiza prospektywna skupi się natomiast na uwarunkowaniach tworzenia budżetu unijnego na lata 2021-2027. 


\section{Perspektywa finansowa lat 2000-2006}

Wieloletnie Ramy Finansowe na lata 2000-2006 przedstawione zostały w komunikacie pn. Agenda 2000. Jednym z podstawowych wyzwań budżetowych była wówczas kwestia finansowania wstępujących w struktury unijne „nowych” (w ówczesnym czasie) państw członkowskich. Po negocjacjach, podczas posiedzenia Rady Europejskiej w Berlinie w dniach 24 i 25 marca 1999 r., wypracowano kompromis pozwalający wszystkim dotychczasowym beneficjentom na zachowanie poziomu dotacji, a płatnikom na nie zwiększanie ich obciążeń. Przyjęto też wspólne rozwiązanie umożliwiające rozszerzenie Unii Europejskiej przy utrzymaniu obowiązujących limitów wielkości budżetu UE (tj. nie więcej niż 1,24\% PNB w latach 2000-2006). Wieloletnie Ramy Finansowe w latach 2000-2006 przedstawia tabela 1.

Tabela 1. Wieloletnie Ramy Finansowe 2000-2006 [mld euro]

\begin{tabular}{|c|c|c|c|c|c|c|c|c|}
\hline Środki na zobowiązania & 2000 & 2001 & 2002 & 2003 & 2004 & 2005 & 2006 & \begin{tabular}{|l} 
Łącznie \\
$2000-06$ \\
\end{tabular} \\
\hline 1. Rolnictwo & 41738 & 44530 & 46587 & 47378 & 49305 & 51439 & 52618 & 333595 \\
\hline 2. Operacje strukturalne & 32678 & 32720 & 33638 & 33968 & 41035 & 42441 & 44617 & 261097 \\
\hline 3. Polityki wewnętrzne & 6031 & 6272 & 6558 & 6796 & 8722 & 9012 & 9385 & 52776 \\
\hline 4. Działania zewnętrzne & 4627 & 4735 & 4873 & 4972 & 5082 & 5119 & 5269 & 34677 \\
\hline 5. Administracja & 4638 & 4776 & 5012 & 5211 & 5983 & 6185 & 6528 & 38333 \\
\hline 6. Rekompensaty & 906 & 916 & 676 & 434 & 442 & 446 & 458 & 4278 \\
\hline $\begin{array}{l}\text { 7. Pomoc } \\
\text { przedakcesyjna }\end{array}$ & 3174 & 3240 & 3328 & 3386 & 3455 & 3472 & 3556 & 23621 \\
\hline 8. Rozszerzenie & & & & & 1410 & 1305 & 1074 & 3789 \\
\hline $\begin{array}{l}\text { Łącznie środki } \\
\text { na zobowiązania }\end{array}$ & 93792 & 97189 & 100672 & 102145 & 115434 & 119419 & 123515 & 752166 \\
\hline $\begin{array}{l}\text { Lącznie środki } \\
\text { na płatności }\end{array}$ & 91322 & 94730 & 100078 & 102767 & 111380 & 114060 & $\begin{array}{lll}119 & 112 \\
\end{array}$ & 733449 \\
\hline
\end{tabular}

Źródło: [EU Budget 2006 - Financial Report 2007].

W stosunku do budżetu wieloletniego z lat 1994-1999 dokonano pewnych zmian w procedurze budżetowej oraz zasadach jej tworzenia. Zmiany dotyczące samej procedury były niewielkie i dotyczyły procedury koncyliacyjnej, która miała być rozszerzona tak, aby objąć wydatki obligatoryjne i nieobligatoryjne. Obowiązywanie przewidziano na cały proces ustalania budżetu. Drugą kwestią były szerokie ujęcia sklasyfikowanych wydatków wyznaczane wytycznymi [Żukrowska 2009].

Wprowadzono też kilka ograniczeń, mających uściślić obowiązujące zasady budżetowe. Ustalono m. in., że nie można przenosić kwot niewykorzystanych z jednego roku na drugi. Wyjątkiem było niezrealizowanie finansowania danego programu z powodu opóźnień. Innym ustaleniem było przyjęcie, że alokacje dla krajów przedakcesyjnych są alokacjami ustalonymi i nie należy ich zmieniać. Zastosowano również instrument pozwalający na elastyczność posiadanych środków. Można było 
zagwarantować środki finansowe na konkretny rok i na konkretny cel. Finansowanie celu nie mogło odbyć się poniżej ustalonego pułapu [Żukrowska 2009].

$\mathrm{W}$ trakcie prac nad budżetem wieloletnim pojawiło się kilka problemów natury merytorycznej: kwestia rabatu brytyjskiego, stosowanie przeliczników kursowych $\mathrm{z}$ walut narodowych na euro czy ustalanie konkretnych pułapów na dane działy. Jednakże budżet unijny w tym okresie nie był narażony na większe napięcia.

\section{Perspektywa finansowa lat 2007-2013}

Wieloletni budżet na lata 2007-2013 został określony w Porozumieniu Międzyinstytucjonalnym zawartym w 2006 r. przez Komisję Europejską, Radę i Parlament Europejski. Zmienił się w nim nieznacznie układ pozycji wydatków. $Z$ oczywistych przyczyn pominięto finansowanie pomocy przedakcesyjnej i rozszerzenia. Wprawdzie od 1 stycznia 2007 r. członkami UE stały się Rumunia i Bułgaria, jednak wydatki dla tych krajów uwzględniono w ramach nowo oszacowanych pozycji budżetowych. W Wieloletnich Ramach Finansowych zmieniły się przede wszystkim priorytety finansowania działalności Unii. Podyktowane zostało to koniecznością realizacji zapisów przyjętych w odnowionej strategii lizbońskiej. Głównym celem stało się wzmocnienie konkurencyjności gospodarki Unii na świecie oraz niwelowanie różnic w poziomie rozwoju gospodarczego między krajami członkowskimi. Istotne znaczenie zyskała ochrona zasobów naturalnych, do której włączono wydatki na rolnictwo [Oręziak 2009]. Wieloletnie Ramy Finansowe lat 2007-2013 przedstawia tabela 2 .

Tabela 2. Wieloletnie Ramy Finansowe lat 2007-2013 [mld euro]

\begin{tabular}{|l|r|r|r|r|r|r|r|r|}
\hline $\begin{array}{c}\text { Środki } \\
\text { na zobowiązania }\end{array}$ & 2007 & 2008 & 2009 & 2010 & 2011 & 2012 & 2013 & $\begin{array}{r}\text { Lącznie } \\
2007-13\end{array}$ \\
\hline $\begin{array}{l}\text { 1. Zrównoważony } \\
\text { rozwój }\end{array}$ & 54405 & 56736 & 59197 & 61144 & 63601 & 66640 & 69678 & 431401 \\
\hline $\begin{array}{l}\text { 2. Zarządzanie zaso- } \\
\text { bami naturalnymi }\end{array}$ & 58351 & 58800 & 59252 & 59726 & 60191 & 60663 & 61143 & 418125 \\
\hline $\begin{array}{l}\text { 3. Obywatelstwo, } \\
\text { wolność, obrona } \\
\text { i sprawiedliwość }\end{array}$ & 1237 & 1362 & 1523 & 1639 & 1889 & 2105 & 2376 & 12221 \\
\hline $\begin{array}{l}\text { 4. UE jako partner } \\
\text { globalny }\end{array}$ & 6578 & 7002 & 7440 & 7893 & 8430 & 8997 & 9595 & 55935 \\
\hline $\begin{array}{l}\text { 5. Administracja } \\
\text { 6. Rekompensaty }\end{array}$ & 7439 & 7380 & 7699 & 8008 & 8334 & 8670 & 9095 & 56225 \\
\hline $\begin{array}{l}\text { Lącznie środki } \\
\text { na zobowiązania }\end{array}$ & 128091 & 131487 & 135321 & 138464 & 142445 & 147075 & 151886 & 974769 \\
\hline $\begin{array}{l}\text { Lącznie środki } \\
\text { na płatności }\end{array}$ & 123790 & 129481 & 123646 & 133202 & 133087 & 139908 & 142180 & 925294 \\
\hline
\end{tabular}

Źródło: [EU Budget 2006 - Financial Report 2007]. 
Podczas perspektywy finansowej 2007-2013 wprowadzono uproszczenia mające zapewnić ułatwienie dostępu do funduszy unijnych podmiotom, które dotychczas nie miały możliwości wykorzystania środków. Przewidziano również ograniczenia dotyczące środków własnych, koniecznych do uruchomienia dofinansowania. Uproszczone zostały także formuły wymagane przy sprawozdaniach oraz kontrola przebiegu realizacji finansowanych projektów. Istotne znaczenie przypisano grantom unijnym, które stały się formą bezpośredniego wsparcia małych i średnich przedsiębiorstw. Większość środków udostępniana była poprzez instytucje krajowe i regionalne, pośredniczące $\mathrm{w}$ procesie pozyskiwania funduszy budżetowych [Żukrowska 2009].

Analizując budżet lat 2007-2013, należy stwierdzić, że nie przeszedł on radykalnych przemian. Wcześniejsze gruntowne reformy okazały się bowiem na tyle racjonalne, że doprowadziły do zapewnienia stabilności budżetowej. Finansowanie działalności UE odbywało się zatem w tym okresie bez większych zarzutów.

\section{Perspektywa finansowa lat 2014-2020}

W listopadzie 2013 r. Parlament Europejski przegłosował kolejne Wieloletnie Ramy Finansowe. W latach 2014-2020 prognozowane wydatki w zobowiązaniach wyniosły 960 mld euro oraz ponad 908 mld euro w płatnościach (w cenach z 2011 r.) [Rozporządzenie Rady z 2 grudnia 2013]. Wartości te okazały się odpowiednio o 3,4\% i 3,7\% mniejsze niż w latach 2007-2013. Po raz pierwszy w historii zaistniała sytuacja, w której WRF były realnie mniejsze niż poprzednia perspektywa finansowa.

W cenach bieżących wartości wydatków okazały się wyższe i stanowiły ponad 1082 mld euro w zobowiązaniach i ok. 1024 mld euro w płatnościach [Multiannual Financial... 2013]. Po zaktualizowaniu WRF na rok 2018, wartości wydatków kształtują się odpowiednio na poziomie ponad 1087 mld euro i 1026 mld euro [http:// ec.europa.eu].

Istotne zmiany w bieżącym okresie funkcjonowania WRF związane są z polityką spójności, na którą przeznaczono aż 325 mld euro (ceny z 2011 r.), wkomponowując tę kwotę w dział budżetowy pn. Inteligentny wzrost gospodarczy sprzyjający włączeniu społecznemu. Priorytetem w tej sferze stało się finansowanie badań i rozwoju, wspieranie małych i średnich przedsiębiorstw, poprawa wydajności energetycznej, inwestycje w odnawialne źródła energii, walka z bezrobociem i ubóstwem oraz tworzenie miejsc pracy. W WRF wskazano zasadę tzw. warunkowości makroekonomicznej. Zgodnie z nią istnieje możliwość zablokowania środków europejskich w sytuacji, gdy polityka rządów państw unijnych prowadzić będzie do zaburzeń w gospodarce. Łagodniejszą konsekwencją zastosowania zasady warunkowości makroekonomicznej jest żądanie Komisji Europejskiej zmiany umów partnerstwa i programów operacyjnych, będących podstawą wydatkowania środków unijnych. Wystąpienie z żądaniem możliwe jest w sytuacji stwierdzenia problemów 
gospodarczych i dotyczących zatrudnienia w danym państwie członkowskim [Rozporządzenie Parlamentu Europejskiego z 17 grudnia 2013].

Kolejną ważną kwestią było wprowadzenie zasady elastyczności, co oznacza możliwość przesuwania niewykorzystanych środków z roku na rok oraz pomiędzy działami budżetu. To swoiste novum, jako że elastyczność nie była stosowana w okresach poprzednich [Żukrowska 2009]. Wieloletnie Ramy Finansowe lat 2014-2020 przedstawia tabela 3.

Tabela 3. Wieloletnie Ramy Finansowe lat 2014-2020 [mld euro, ceny bieżące]

\begin{tabular}{|l|r|r|r|r|r|r|r|r|}
\hline $\begin{array}{c}\text { Ś́ndki } \\
\text { na zobowiązania }\end{array}$ & 2014 & 2015 & 2016 & 2017 & 2018 & 2019 & 2020 & $\begin{array}{r}\text { Łącznie } \\
2014-20\end{array}$ \\
\hline $\begin{array}{l}\text { 1. Inteligentny } \\
\text { wzrost gospo- } \\
\text { darczy sprzyja- } \\
\text { jący włączeniu } \\
\text { społecznemu }\end{array}$ & 63973 & 66813 & 69304 & 72342 & 75271 & 78752 & 82466 & 508921 \\
\hline $\begin{array}{l}\text { 2. Trwały wzrost } \\
\text { gospodarczy: } \\
\text { zasoby naturalne }\end{array}$ & 59303 & 56599 & 59909 & 60191 & 60267 & 60344 & 60421 & 420034 \\
\hline $\begin{array}{l}\text { 3. Bezpieczeństwo } \\
\text { i obywatelstwo }\end{array}$ & 2179 & 2246 & 2378 & 2514 & 2656 & 2801 & 2951 & 17725 \\
\hline $\begin{array}{l}4 . \text { Globalny wymiar } \\
\text { Europy }\end{array}$ & 8335 & 8749 & 9143 & 9432 & 9825 & 10268 & 10510 & 66262 \\
\hline 5. Administracja & 8721 & 9076 & 9483 & 9918 & 10346 & 10786 & 11254 & 69584 \\
\hline 6. Rekompensaty & 29 & 0 & 0 & 0 & 0 & 0 & 0 & 29 \\
\hline $\begin{array}{l}\text { Lącznie środki } \\
\text { na zobowiązania }\end{array}$ & 142540 & 146483 & 150217 & 154397 & 158365 & 162951 & 167602 & 1082555 \\
\hline $\begin{array}{l}\text { Lącznie środki } \\
\text { na płatności }\end{array}$ & 135866 & 141901 & 144685 & 142771 & 149074 & 153362 & 156295 & 1023954 \\
\hline
\end{tabular}

Źródło: [Multiannual Financial... 2013].

W wieloletnim budżecie unijnym lat 2014-2020 Polsce alokowano 105,8 mld euro, w tym na politykę spójności 72,9 mld euro, a na politykę rolną 28,5 mld euro. Jest to o ok. 4,5 mld euro więcej niż w latach 2007-2013.

\section{Zmienność działów i wielkości wydatków budżetowych 2000-2020}

Każda z perspektyw finansowych powoduje zmiany wieloletniego budżetu Unii Europejskiej. Uwidaczniają się one w nazewnictwie i hierarchii pozycji budżetowych, wielkości wydatków oraz wprowadzaniu nowych regulacji w zakresie niektórych procedur. Przeobrażenia budżetowe są oczywistą i naturalną konsekwencją analizy racjonalności dotychczas wydatkowanych środków, uwzględniają kwestie zmian te- 
rytorialnych Unii oraz ujmują nowo wytyczane kierunki rozwojowe Wspólnoty, przyjmowane w kolejnych strategiach rozwojowych (strategia lizbońska, strategia Europa 2020). Porównanie działów i wielkości wydatków budżetowych Unii Europejskiej w latach 2000-2020 przedstawia tabela 4.

Tabela 4. Działy i wielkość wydatków budżetowych w latach 2000-2020 [mld euro]

\begin{tabular}{|c|c|c|c|c|c|}
\hline \begin{tabular}{|c|} 
Środki \\
na zobowiązania
\end{tabular} & \begin{tabular}{|c|} 
Łącznie \\
$2000-2006$
\end{tabular} & $\begin{array}{c}\text { Środki } \\
\text { na zobowiązania }\end{array}$ & $\begin{array}{c}\text { Łącznie } \\
2007-2013\end{array}$ & $\begin{array}{c}\text { Środki } \\
\text { na zobowiązania }\end{array}$ & $\begin{array}{c}\text { Łącznie } \\
2014-2020\end{array}$ \\
\hline 1. Rolnictwo & 333595 & $\begin{array}{l}\text { 1. Zrównoważony } \\
\text { rozwój }\end{array}$ & 431401 & $\begin{array}{l}\text { 1. Inteligentny } \\
\text { wzrost gospodar- } \\
\text { czy sprzyjający } \\
\text { włączeniu spo- } \\
\text { łecznemu } \\
\end{array}$ & 508921 \\
\hline $\begin{array}{l}\text { 2. Operacje } \\
\text { strukturalne }\end{array}$ & 261097 & $\begin{array}{l}\text { 2. Zarządzanie } \\
\text { zasobami } \\
\text { naturalnymi }\end{array}$ & 418125 & $\begin{array}{l}\text { 2. Trwały wzrost } \\
\text { gospodarczy: } \\
\text { zasoby naturalne }\end{array}$ & 420034 \\
\hline $\begin{array}{l}\text { 3. Polityki } \\
\text { wewnętrzne }\end{array}$ & 52776 & $\begin{array}{l}\text { 3. Obywatelstwo, } \\
\text { wolność, obro- } \\
\text { na i sprawiedli- } \\
\text { wość }\end{array}$ & 12221 & $\begin{array}{l}\text { 3. Bezpieczeństwo } \\
\text { i obywatelstwo }\end{array}$ & 17725 \\
\hline $\begin{array}{l}\text { 4. Działania } \\
\text { zewnętrzne }\end{array}$ & 34677 & $\begin{array}{l}\text { 4. UE jako part- } \\
\text { ner globalny }\end{array}$ & 55935 & $\begin{array}{l}\text { 4. Globalny wymiar } \\
\text { Europy }\end{array}$ & 66262 \\
\hline 5. Administracja & 38333 & 5. Administracja & 56225 & 5. Administracja & 69584 \\
\hline 6. Rekompensaty & 4278 & 6. Rekompensaty & 862 & 6. Rekompensaty & 29 \\
\hline $\begin{array}{l}\text { 7. Pomoc } \\
\text { przedakcesyjna }\end{array}$ & 23621 & & & & \\
\hline 8. Rozszerzenie & 3789 & & & & \\
\hline $\begin{array}{l}\text { Łącznie środki } \\
\text { na zobowiązania }\end{array}$ & 752166 & $\begin{array}{l}\text { Łącznie środki } \\
\text { na zobowiązania }\end{array}$ & 974769 & $\begin{array}{l}\text { Łącznie środki } \\
\text { na zobowiązania }\end{array}$ & 1082555 \\
\hline $\begin{array}{l}\text { Łącznie środki } \\
\text { na płatności }\end{array}$ & 733449 & $\begin{array}{l}\text { Łącznie środki } \\
\text { na płatności }\end{array}$ & 925294 & $\begin{array}{l}\text { Łącznie środki } \\
\text { na płatności }\end{array}$ & 1023954 \\
\hline
\end{tabular}

Źródło: opracowanie własne.

Analiza WRF pozwala zauważyć, że pierwszoplanową rolę utraciły wydatki na rolnictwo. W dwóch ostatnich perspektywach finansowych przesunięto je do działu 2. i umieszczano w obszarze wydatków dotyczących gospodarowania zasobami naturalnymi.

W przekroju dwóch ostatnich budżetów w dziale 1. kwalifikowane były środki na działania gospodarczo-społeczne (Zrównoważony rozwój, Inteligentny wzrost gospodarczy sprzyjający włączeniu społecznemu), w tym obejmujące unijną politykę spójności i zatrudnienie. Odnotowano znaczny ich wzrost, wyraźnie przewyższający wydatki na rolnictwo, szczególnie w latach 2014-2020. Nie oznacza to wszakże deprecjonowania rolnictwa, a jedynie potrzebę silniejszego wzmocnienia Unii od strony strukturalnej i regionalnej. 
Bez zmian, w dziale 3., uwidaczniane były wydatki na niektóre polityki wewnętrzne. Ograniczone zostało jednak ich finansowanie. Jeszcze w latach 2000-2006 wydatkowano tu ponad 52 mld euro, podczas gdy przedostania i ostania perspektywa finansowa uwzględniły finansowanie na poziomie odpowiednio nieco ponad 12 mld euro i ok. 18 mld euro. Tym samym państwa członkowskie UE obarczone zostały w większym stopniu finansowaniem własnym.

Dział 4., przeznaczony na unijne działania w skali międzynarodowej, wykazuje sukcesywny wzrost wydatków: porównując budżety z lat 2014-2020 i 2000-2006, nastąpiło tu niemal podwojenie finansowania. Zagwarantowane aktualnie środki przeznaczane są na współpracę naukową z kluczowymi organizacjami międzynarodowymi i państwami trzecimi (np. z organami ONZ, OECD, USA, Japonią, Rosją, Chinami, Brazylią i Indiami) w dziedzinach o wyraźnie globalnym charakterze, takich jak zmiana klimatu, bezpieczeństwo żywności lub nanotechnologie.

Trwale zakorzenionym działem w strukturze budżetu jest administracja. Wydatki w tym obszarze finansują utrzymanie instytucji europejskich i rocznie pochłaniają ok. $6 \%$ budżetu UE. Wykorzystywane są one na opłacanie urzędników pracujących w Parlamencie Europejskim, Radzie UE, Komisji Europejskiej, Europejskim Trybunale Sprawiedliwości, Europejskim Trybunale Obrachunkowym, Komitecie Regionów i innych. Finansowanie dotyczy też kosztów funkcjonowania Unii w jej 24 językach urzędowych [Janiak 2015]. Rozrost wydatków na administrację podyktowany został m.in. kolejnymi rozszerzeniami Wspólnoty, jednakże biurokracja unijna każdorazowo podlega ostrej krytyce. Warto przy tym zwrócić uwagę, że np. na tle funkcjonowania przedsiębiorstw czy organizacji pozarządowych w Polsce 6-procentowy udział kosztów administracyjnych w budżecie UE jest stosunkowo niewielki.

Dział 6. Rekompensaty obejmuje przede wszystkim czasowe wsparcie dla mniej zamożnych państw. Pojawiają się tu środki przeznaczane na rezerwy, np. monetarna (na pokrycie wahań kursowych euro i dolara w ramach Europejskiego Systemu Monetarnego), na gwarancje pożyczkowe państwom trzecim czy pomoc nadzwyczajną dla państw spoza UE [Soboń 2008]. Rekompensaty nie odgrywają szczególnej pozycji w strukturze Wieloletnich Ram Finansowych. Aktualnie obserwowalne jest malejące znaczenie tego działu.

\section{Perspektywa finansowa lat 2021-2027}

Ostateczny kształt nowych Wieloletnich Ram Finansowych będzie znany dopiero w roku 2020. W maju 2018 r. ma zostać przedstawiony ich wstępny projekt. Komisja Europejska prawdopodobnie zaprezentuje pomysł wprowadzenia ograniczeń w uzyskiwaniu środków w odniesieniu do państw nie przestrzegających unijnych zasad praworządności. Propozycja ta dotyczyć może przede wszystkim Węgier i Polski, pozostających od dłuższego czasu w sporze z Komisją Europejską. Prawdopodobnie forsowana będzie koncepcja cięć przyznanych środków, o ile państwa członkowskie 
będą ignorować zalecenia Komisji Europejskiej w sprawie konkretnych reform czy kwestii [http://www.rp.pl].

Konstrukcja nowego wieloletniego budżetu obowiązkowo musi uwzględnić brexit. Oznacza to, że wszystkie przyszłe wydatki państw członkowskich będą niższe. Warto zauważyć, że brexit spowoduje spadek wpłat do unijnej kasy na poziomie ok. 13 mld euro rocznie [http://businessinsider.com.pl].

Wśród modyfikacji budżetowych znajduje się także propozycja zmiany priorytetów oraz wprowadzenia jeszcze większej elastyczności wydatkowania środków. Dotyczy to głównie sytuacji nadzwyczajnych, takich jak kryzys migracyjny, wymagających angażowania pokaźnych funduszy. Elastyczność ma być związana nie tylko z możliwościami przesunięć środków, ale także z ich odbieraniem. Możliwe jest także finansowe wzmocnienie bezpieczeństwa wewnętrznego i zewnętrznego oraz dodatkowe wparcie polityki migracyjnej. W związku z ograniczonością wydatków budżetowych analizowana jest również możliwość cięć wydatków budżetowych wobec krajów, które nie ograniczają nadmiernych deficytów budżetowych. Po raz pierwszy w historii finansowanie mogą zyskać projekty związane z obronnością [http://www.obserwatorfinansowy.pl].

Przedstawione zamierzenia, zawarte we wstępnym projekcie założeń przyszłej perspektywy finansowej, przekładają się na strategię docelowego ograniczenia funduszy unijnych państwom członkowskim. Jednym z państw, które może ona najboleśniej dotknąć, będzie najprawdopodobniej Polska.

\section{Zakończenie}

Od roku 2000 wieloletni budżet unijny ewoluował stopniowo. W trzech ostatnich perspektywach finansowych nie przeprowadzano w nim głębokich i radykalnych reform. Dokonywane w minionych okresach modyfikacje należy traktować jako mniejsze lub większe poprawki konieczne ze względu na zmiany ekonomiczne w gospodarce europejskiej i światowej.

Istotną kwestią, która pojawiła po raz pierwszy w historii, było zmniejszenie ogólnej sumy wydatków na zobowiązania i płatności w perspektywie finansowej lat 2014-2020, określonych według cen z 2011 r. W cenach bieżących wydatki okazały się wyższe, zarówno w zobowiązaniach, jak i w płatnościach, i przekroczyły 1 bln euro.

Nastąpiło wyraźne przesuniecie priorytetów budżetowych. W dwóch ostatnich budżetach wieloletnich największe kwoty środków przeznaczano na poprawę funkcjonowania gospodarek i społeczeństwa (głównie polityka spójności i zatrudnienie). Rolę drugoplanowego priorytetu zaczęło odgrywać rolnictwo. Pozostałe działy budżetowe (funkcjonujące pod zmiennymi nazwami, ale w rzeczywistości dotyczące wybranych polityk wewnętrznych Unii, jej działań zewnętrznych, wydatków administracyjnych i rekompensat) okazały się na stałe zakotwiczone w strukturze Wieloletnich Ram Finansowych. Zaobserwowano przy tym dużo mniejsze finansowanie 
unijnych polityk wewnętrznych oraz zwiększenie wydatków na działania zewnętrzne i administrację. Marginalną i malejącą rolę odgrywają rekompensaty.

Wobec braku planów znacznego poszerzenia Wspólnoty (oprócz Chorwacji w 2013 r.) z perspektyw finansowych lat 2007-2013 i 2014-2020 w naturalny sposób wyeliminowano wydatki na pomoc przedakcesyjną i rozszerzenie.

W niedługim czasie dojdzie do przyjęcia nowej perspektywy finansowej na lata 2021-2027. Z uwagi na brexit należy spodziewać się radykalnych przeobrażeń finansowych i zmniejszenia wydatków. Proponowane zmiany, zwłaszcza możliwość uzależnienia wydatków od przestrzegania zasad praworządności, oznaczać będą dużo mniejsze środki dla Polski.

\section{Literatura}

Cieślukowski M., 2006, Budżet Unii Europejskiej, Poznań, s. 15.

EU Budget 2006 - Financial Report, 2007, European Commission, Luxemburg, s. 37.

https://businessinsider.com.pl/finanse/makroekonomia/polityka-spojnosci-po-2020-roku-ciecia-w-budzecie-ue/vdx 1 nnt (3.03.2018).

http://ec.europa.eu (3.03.2018).

https://www.obserwatorfinansowy.pl/forma/rotator/rozpoczyna-sie-gra-o-finanse-ue-po-2020-r/ (3.03.2018).

http://www.rp.pl/Unia-Europejska/302149913-Unijne-pieniadze-tylko-dla-praworzadnych.html (3.03.2018).

Janiak M., 2015, Budżet Unii Europejskiej, Ministerstwo Spraw Zagranicznych, Warszawa, s. 2.

Multiannual Financial Framework 2014-2020 and EU budget 2014, 2013, European Commission, Luxemburg, s. 8.

Oręziak L., 2009, Finanse Unii Europejskiej, Wydawnictwo Naukowe PWN, Warszawa, s. 126-138.

Rozporządzenie Parlamentu Europejskiego i Rady (UE) nr 1303/2013 z 17 grudnia 2013 ustanawiające wspólne przepisy dotyczące Europejskiego Funduszu Rozwoju Regionalnego, Europejskiego Funduszu Społecznego, Funduszu Spójności, Europejskiego Funduszu Rolnego na rzecz Rozwoju Obszarów Wiejskich oraz Europejskiego Funduszu Morskiego i Rybackiego oraz ustanawiające przepisy ogólne dotyczące Europejskiego Funduszu Rozwoju Regionalnego, Europejskiego Funduszu Społecznego, Funduszu Spójności i Europejskiego Funduszu Morskiego i Rybackiego oraz uchylające rozporządzenie Rady (WE) nr 1083/2006, Dz.Urz. UE L 347/320.

Rozporządzenie Rady nr 1311/2013 z 2 grudnia 2013 określające wieloletnie ramy finansowe na lata 2014-2020, Dz.Urz. UE L 347/884.

Soboń J., 2008, Budżet Unii Europejskiej, Oficyna Wydawnicza ASPRA-JR, Warszawa, s. 35.

Żukrowska K., 2009, Budżet ogólny Unii Europejskiej, Wydawnictwa Akademickie i Profesjonalne, Warszawa, s. 202-211. 